\title{
IN'TERPRETATIONS AND EMENDATIONS OF EARLY ENGLISH TEXTS.
}

(Cf. Anglia N. F. XIII, XIV.)

III.

This section shall be devoted chiefly to some passages in Beowulf (cf. the list on pp. 236-237). I shall quote the following editions, translations, and other works relative to the subject:

AfdA. = Anzeiger für deutsches Altertum und dentsche Philologie.

Archiv = Archiv für das Studium der neueren Sprachen.

Barnouw, Textkritische Untersuchungen nach dem Gebrauch des best. Artikels, Leiden 1902.

Beitr. = Beiträge zur Gesch. d. dentschen Spr. und Literatur.

TEN BRINK, Untersuchnngen, in Quellen u. Forsch. no. 62, Strassburg 1888. Bosworth-Toller, An Anglo-Saxon Dictionary, 0xford 1882-1898.

Cosiss, Aanteekeningen op den Beowulf, Leiden 1892.

ESt. = Englische Studien.

GarnetT (translation), Boston 1885.

Grein, Bibliothek der ags. Poesie, Cassel und Göttingen 1857-1864.

GrundTvig (edition), Kjöbenhavn 1861.

HALL (translation), London 1901.

Heyne-Socin (edition), Paderborn (1888) 1898. [Cf. Postscript.]

Holder (edition), Freiburg 1899.

KEMBLE (edition), London 1837.

Thorpe (edition), Oxford 1855.

Sievers, Beowulf und Saxo, in Ber. ü. d. Verhandl. d. kgl. sächs. Gesellsch.

d. Wiss. zu Leipzig, Philol.-histor. Classe, 1895.

Sweet, An Anglo-Saxon Reader, Oxford 1898.

Trautmann, Berichtigungen, Vermutungen und Erklärungen zum Beowulf, in Bonner Beiträge zur Anglistik, Heft II, 1899.

WüLCKER, Bibliothek der ags. Poesie I, Kassel 1881 (1883).

WyatT (edition), Cambridge 1901.

ZfdA. = Zeitschrift für deutsches Altertum.

$\mathrm{ZfdPh} .=$ Zeitschrift für deutsche Philologie.

ZupitzA (edition), E. E. T. S. 77, London 1882.

Where one of the above authors is mentioned without book-title, the work here indicated is alluded to. 
KOCK, NNTERPRET. AND EMEND. OF EARLY ENGLISH TEXTS. 219

60. Oft Scyld Scefing sceapen[a] preatum, monezum mozbum, meodu-setla ofteah, ezsode eorl, syððan arest weard

- fea-sceaft funden 4-7.

Far zenehost brazd

eorl Beowolfes ealde lafe 794-795.

$\bar{p}_{\text {aer }}$ on bence was

ofer apelinze yp-zesene

heapo-steapa helm, hrinzed byrne 1243-45.

HeYNE-Socn take eorl in 1.6 to be the subject of the clause, the word being used of king Scyld, and ezsode to be an intransitive verb: "had experienced terror, or trouble". This is to give to the verb a signification which it is not known to have elsewhere. 1) Grein, GarnetT, and Howdrer likewise look on eorl as the subject, but allow the verb to keep its usual, transitive, meaning: "the earl frightened, caused terror". However, we miss an object, the more so on account of the expected parallelism of the members (ofteah + objectives $=$ ezsode + objective). Kemble, Thorpe, Sievirrs, Trautmann, Barnouw:) therefore take the noun to be the object, but do not approve of it in its present shape: sense, or rhythm, or both, they think, require the plural eorlas. I have quoted the two other passages out of Beowulf in order to show that there is no necessity for such an alteration as far as the meaning is concerned. Eorl in both instances and opelinze in 1.1244 are singular in form, plural in sense. ${ }^{3}$ ) And it is not advisable to build much on metrical theories. Who has actually proved that ezsode eorl, earlier ézsòdae eorl, is "zu kurz", or more "falsch", or "anstössig", or "mangelhaft"

1) Cf. Sievers, Trautmans.

2) p. 27.

3) Heyne-Socin's 5th edition referred apelinze to Beowulf, although 1. 1299 states expressly: Nas Beowulf $\delta a r$. In the 6th edition the error is corrected, and the right explanation is given, introduced however by a hesitative "vielleicht". It is sure enough that the word is used, just as beor-scealca sum 1240, with reference to all those of king Hroogar's men, unrim eorla 1238, who stayed in the Hall, after the king - as well as Beowulf - had retired, and who there, when making preparations to go to sleep, true to their custom, kept their arms beside them: over the warrior's head was seen his helmet and corslet. 
(Sievers, Trautmann, Sarrazin 1), Barnouw) than unfīezne eorl 573, andlònze éorl 2695? or that zyddode pus Metr. 1:84 ought to be twisted about, or that irena cyst 673 (= irenna cyst 802 ) requires an emendation? I therefore unscrupulously recommend the retaining of the line in its handed-down shape and translate it: "terrified many a warrior".2)

\section{1. poet hine on ylde eft zewunizen wil-zesipas, bonne wiz cume, leode zelasten 22-24.}

\section{bonne his sunu hanzad}

hrefne to hrodre, and he him helpan ne moz, eald and infrod, anize zefremman 2447-49.

The structure of the former sentence is misrepresented in Boswonth-Toller's "Đat hine donne wig come leode gelaesten, that the people serve him when war comes", in HeYne-Socis's "c. acc. pers.: pät hine ... leode gelcesten", and in WyaTT's "gelcestan, with acc. or dat., serve". There is no hine .. zeloesten in this sentence, nor in any other. It is the verb zewunizen alone that governs the accusative case; zeloesten, in the sense of "follow", "serve", here and always requires the dative. But the poet felt no necessity of repeating, in another shape, the pronoun of the former verb before the latter; hine serves for a him as

1) Engl. Stud. 28, 407.

2) Even where a line is metrically faulty, we should not confuse two so different objects as 1 . the interpretation and emendation of a text such as it actually appears in a late unique MS., and 2. the restoration of the original text. Verses which, in all probability, appeared right enough to an average 10th century hearer or scribe, are justifiable in their way, quite independently of the fact that the poem had gradually assumed a shape very different from the original one. Whoever thinks he can, in part at least, trace that original shape, let him do so; let him not content himself with accepting whatever gives an acceptable meaning, and emending only what seems to be a blunder or give no sense at all; let him also rearrange words, phrases, clauses, lines; let him give a large number of notes on the text, or even publish a separate, reconstructed Beowulf, which we will receive with more or less confidence and gratitude; but let him forego his claims (see e. g. Trautmann in Anglia Beibl. 10, 257-258) on having his, or anybody else's, "7th century" guesses introduced into ordinary editions of the 10th century tert! 
well. The same phenomenon, as important as it is simple, meets us in the latter of the passages quoted. Helpan, whether only "vom Schreiber als Infinitiv gemeint "(SIEvers 1)), or used by the poet himself, is an infinitive and governs the dative case. (Kemble, Thorpe, Rieger ${ }^{2}$ ), Bosworth-Toller p. 592 a substitute helpe; Grein, Heyne-Socin, WyatTt, BosworthTOLLER p. $527 \mathrm{~b}$ assume a weak helpe, acc. helpan, not otherwise known.) Annize, whether originally meant for an accusative or not, appears here as an instrumental: "by anything", "in any way". Jefremman requires an accusative; and the acc. can be mentally supplied out of $\mathrm{him}$. The sentence, as it stands, means: "and he, old and stricken in years, cannot help him, assist him in any way". Further examples: Beow. 47-49, 673-674, Genesis 250-251 (misunderstood by EтTMüller and RIEGER ${ }^{2}$ )). Finally I will mention instances like: weana zehwelcne, sidra sorza Beow. 148-149, where zehwelcne includes zehwelce.

62. swa he selfa boed, penden wordum weold wine Scyldinza, leof land-fruma lanze ahte 29-31.

The old king Scyld was dead. His men placed his remains on a ship, "as he himself had bidden, whilst the Scyldings' friend could give orders, [whilst] the dear prince of the country ..." Here it seems hard to find a good continuation. Many attempts have been made, but all, I believe, in vain. THORPE and Grein make of the last line an independent clause: he had long been owner (viz. of the land). BuGGE ${ }^{3}$ ) places it after 1.32. HEYNE-Socin, not willing to sacrifice the parallelism of the members, want zeweald to be mentally supplied (out of wordum weold in the preceding line): "[whilst] the dear prince had long possessed the power". RIEGER "), feeling the want of a proper objective, proposes lif for leof. KLUGE ${ }^{5}$ ), from a similar motive, suggests landazas or land for lanze. LüвKE ()) proposes land leodfruma. CosisN and Trautmann rid themselves of the troublesome objectless verb, the former by the substitution of lange prage, "a long time",
1) $\mathrm{ZfdPh} .21,357$.
2) See WÜLCKER.
3) Beitr. 12, 80 .
4) ZfdPh. 3, 382.
5) Beitr. 9, 188.
6) AfdA. 19, 342 .

Anglia. N. F. $\mathrm{XV}$. 
the latter by the less violent alteration into langre ohte, "the long possession". Sievers 1), despairing of an acceptable emendation, takes recourse to the supposition of a lacuna. Thus there are three points kept in view by the various interpreters: 1. the adhering to the MS. (Thorpe, Grein, Heyne-Socis, in a sense also Sievers), 2. the parallelism of the members (Heyne, Rieger, Kluge, LübKe), 3. the obtaining of an objective (RIEGER, KLUGE, LüBKE), or else the removing of the verb (CosiJn, TrautmanN). Each interpreter has been forced to sacrifice one or two of these points, irreconcilable as they have seemed to be. BugGe, venturesome in his emendatory speculations, throws them all up, and thrusts the whole line into another context. Moreover it may be remarked 2) that Heyne-Socin give no satisfactory proof of the "kühnen, im Beowulf auch sonst nicht unerhörten Konstruktionen, in denen das Objekt eines folgenden Satzgliedes aus einer sinnverwanten Phrase des vorhergehenden zu verstehen ist". There is no corresponding construction in the poem; for those mentioned in No. 61 are very different. RIEGER's and LüBKE's alterations give us an uncommon word-order. Besides, the adverb lanze, both in HeYNe-Socin's and RIEGER's periods, appears out of place. KLUGE's land would, apart from metrical considerations, be a poor tautology, whereas his lcendazas would do well, had we only the smallest certainty for the correctness of the guess. The same may be said of Cosiun's and Trautmann's attempts.

I propose an entirely new way of reading the MS. ${ }^{3)}$, a way which disposes at once of all the difficulties, and reconciles all the various claims. Six lines above, on the same page of the MS., we find manze (end of line) [p]eon, which means man zepeon; on the second next leaf: Neze (end of line) feah, which is Ne zefeah. In the same way I here read: lan zeahte.

Lan, whence the modern loan, is the well-known sideform of laen, due to Scandinavian influence, and quoted by Bosworth-Toller from Codex Diplom. Avi Saxon., ed. Kemble, III 165, 5: he hit hafde to lanlande. Or else we may assume

1) Beitr. 9, 136.

2) Cf. RIEGer, l. c., CosiJn. advertency.

8) The MS. has lanze (end of line) ahte; WÜLCKER's lange is an in- 
the accidental omission of a small loop, a prior copy necessarily having had loen. Jeahte is the past tense of zeazan, "obtain", "possess", not recorded by Boswortr-ToLler, but found in Alfric's Homilies. 1) Compounds given by BosworTHTOLler are the adj. zeazen, the verb zeaznian, and so forth. Lan zeahte means: "possessed the grant", i. e. the land or the transitory life lent him by God (loenland, loene lif, laendazas).

63. Đa was on uhtan mid ar-daze Jrendles zud-croeft zumum undyrne; ba was after wiste wop up ahafen, micel morzen-swez 126-129.

I here emphatically pronounce my approval of Cosiss's and Traummans's view in opposition to Ten Brink's, HeyneSocis's, and HoLDER's. The poet cannot have been unpoetical enough to express the grief of the Danes by saying that they were lamenting "on account of Grendel's food"! Socn's remark: " $\mathrm{Zu}$ Gunsten unserer Erklärung sei verwiesen auf Greins Sprachschatz s. h. v., wo das Flusswasser als Heimat der eszbaren Fische vistum gehladen genannt ist", is not to the point. It would be better to refer to the other passage in the epos itself where the word is used: wunad he on wiste 1735. There it means "eating", "feasting", "enjoyment". The Danes had arranged beds for themselves in the Hall after beorpeze (117); they slept there after symble (119); now there was a wop after wiste: the weal of the evening was followed by woe in the morning.

64. ne par naniz witena wenan porfte beorhtre bote to banan folmum 157-158.

Đonne wene ic to be wyrsan zepinzea deah pu heado-rasa zehwcer dohte 525-526. and him to aniwaldan are selyfde frofre and fultum 1272-73.

Đys dozor pu zebyld hafa weana zehwylces, swa ic pe wene to! 1395-96.

Bosworth-Toller (p. 46 a) translate 1. 1272: "in him as sole ruler reverently trusted"; HEYne-Socin (under to, adv.):

1) SwEET's Reader p. 65, 1. 122. 
"vertraute für sich auf des Allmächtigen Hilfe". The former of these translations requires no refutation; the latter gives the right sense, but shows an entire misapprehension of the syntactical relations. To is not an "adv.", or what I would call a postposition, governing the preceding him; it is a preposition, governing the subsequent anwaldan, which in consequence is not a genitive, but a dative. Him is a reflective dative, which need not exactly be rendered by any special word. The right translation is this: "and believed in help [for himself] from the Monarch (God)". A sufficient proof is the following parallel: se Je him to Jam halzan helpe zelifed, to zode zioce, he poer zearo finded Waldere B 27-28. The construction is the same in the case of wenan: the person for whom something is expected, is expressed by a dative, e. g. hwelces wites ge wenen ठxm pe oðre men reafiað Cura Past. p. 328, 1.13 (E.E.T.S. 50); Ja dieglan satinga, be he him (reflective dative) wenan mog ib. p. 162, 1.14; the person, again, in, or with, or of, or from whom (or the place where, or from where) something is expected, is expressed by to + a dative (or by an adverb: por, etc.), e. g. \#as ilcan is to wenanne to eallum Jam zesceldum pe seo wyrd brenzठ Boethius p. 84, 1.6 (ed. Cardale); aelcum Jara ðe him anges yfles to wend Cura past. p. 451, 1.25; see the numerous examples in WüLfing's Syntax. ${ }^{1)}$ L. $1396 \mathrm{~b}$, therefore, should be rendered: "as I expect of you (from thee)" (BosworthToller p. 991 a, WyatT), not "wie ich dir zuhoffe" (HeyneSociv); l. 158 is misplaced in Hexne-Socin's Glossary (under to I 1). As for 1. 525, Trautmann is right in his opinion that zepinzea (or zepinzes?) does not mean "Verhängnisse" (HEYnESocis), but has the same signification as in ll. 398, 709, i. e. "result"; in all the three lines the word is used in connection with verbs which mean "abide", "wait for". But he shares HEYNe-Socis's error regarding to $p e$, when he translates: "Dann fürcht ich für dich schlechtern ausgang". The line means: "dann erwarte ich von dir schlechteres resultat" (= dass $\mathrm{du}$ in dem kampfe weniger leisten wirst). ${ }^{2)}$

1) Die Syntax in den Werken Alfreds des Grossen, Bonn 1894.

2) The article to in HeYNE-Socis's Glossary is a weak performance also in other respects. Under I $3 \mathrm{~b}$ the editors have jumbled up the most 
65. no he pone zif-stol zretan moste, mapdum for metode, ne his myne wisse 168-169.

Trautmann, the last commentator on these lines, wants, like Holtzmane ') before him, to refer he to Hrodzar, which is simply impossible. The fact that Grendel is the acting personage in the fifteen preceding lines, whereas Hrodzar is not mentioned at all after 1.152 (and not even there as the subject of the sentence), ought in itself to be a sufficient proof, and Trautmans admits that it is "zu beachten". But there is another circumstance which is decisive. "Man sieht sofort ein", says T., "warum Hrodzar den tron nicht berühren durfte: das Grendelübel, mit dem Gott ihn heimsuchte, wehrte es ihm". Similarly Holtzmann. ${ }^{1)}$ This is nonsense. Hrozzar sat on his throne just as before (secz wisode under Heorotes hrof 402-403, poer Hrodzar saet mid his eorla zedriht 356357) - till the dark came on. Then he went to bed (siððan nipende niht, scadu-helma zesceapu, scriðan cwoman 648-650, him Hropzar zewat mid his hoelepa zedryht ut of healle: wolde wiz-fruma Wealhpeo secan, cwen to zebeddan $662-665)$. He used to do so even when no "Grendelübel" threatened (1236-37, 1791-92), and had not the smallest desire to sit up on the throne in sweartum nihtum! In other terms: it was only the using of the Hall as a sleeping-place that was put a stop to by Grendel's visitations. Accordingly Beowulf says to the king, when standing before the throne in Heorot: seczað sa-lidend, poet pes sele stande idel and unnyt, siððan afen-leoht under heofenes hador beholen weorped (411-414).

Thus we may feel satisfied that it was Grendel who could not pone zif-stol zretan. This last expression has carried the thoughts of some (e. g. Grein 2), KörNer ${ }^{2}$ ), TEN Brink) to God's Seat of Mercy - as if that had anything to do with Grendel's nocturnal expeditions. Others have tried to force into it the strange significations "destroy the Hall"

heterogeneous matter. The sentences with the verbs zeliefan, wenan, wilnian ('602', '525', '2923', '188' under I 3, '158' under I 1, '1273' under II 1) are more closely allied to those in I 2 than to '1139'. Different, again, is ' 1579 '; ' 648 ' belongs to I 1 .

1) Germania $8,489 \mathrm{f} . \quad$ 2) See WüLCKer. 
(WÜLCKER $\left.{ }^{1}\right)$ ) and "approach the Altar" (SARRAzIN $\left.{ }^{2}\right)$ ). HeYneSocns and Cosisn believe it denotes the solemn ascending on Hrodzar's throne, the distribution of gifts from it, nay, the wielding of the sceptre over the Danish nation. Fancy Grendel, who never appeared except in the night, a pretender to the Danish throne! Others, again, suppose Grendel, after entering the Hall, to have been prevented by God, or "by a vague awe", from destroying the throne (KöLBING ${ }^{3)}$ ) or even from mounting or touching it (HAl工, BRooke 4)). But what on earth had the demon to do with an empty seat? ${ }^{5)}$ To read of the atrocities committed - and permitted - in $11.740 \mathrm{ff}$., $1294 \mathrm{f} ., 1420 \mathrm{ff}$., and the havoc played in $11.771 \mathrm{ff}$., and yet believe in a special divine care for a piece of furniture! Indeed, after the demon had got into the Hall, he did what he chose. But he did not get in till after dark. That is the point. Only when night set in, and the festive Hall was transformed into a dormitory, did he leave his dismal haunts. He could not partake in the festivities of the day, not step, like the others, before the precious throne to salute the Monarch (and receive his gifts); for he was prevented by the Creator, a stranger to Him. He was excluded from the society and rejoicings of men (dreamum bedacled 721) and bore God's wrath (zodes yrre boer 711), like his ancestor Cain (he pa faz zewat, morpre zemearcod, mandream fleon, westen warode 1263-65). Cf. 1l. 103-114.

To this I will briefly add that GrundTrig supposes a lacuna; Greis translates: "dem gabenstuhle nahen und kleinodgaben heischen"; Pogatscher ${ }^{6}$ ), whose arguments concerning l. 168 coincide with mine, proposes for-metode, "verschmähte", which would both give us a $\alpha \tilde{\pi} \alpha \xi \lambda \varepsilon \gamma o \dot{\alpha} \mu \varepsilon v o v$, and make of the rejected one a rejecter.

Trautmans's doubts of 1.711 are superfluous.

66. Jesloh pin freder foehðe moeste 459.

Tradtmann says: "Es scheint mir völlig unbeweisbar, dass geslean foehðe heissen solle 'einen kampf kämpfen', ganz
1) Anglia 1, $185 \mathrm{f}$.
2) Anglia 19, $369 \mathrm{f}$.
8) ESt. 3, 92.
1) See Beitr. 19, 544 .
5) WüLCKER, l. c., asks the same question.
6) Beitr. 19, $544 \mathrm{f}$. 
abgesehen davon, dass foeh $\partial$ nicht 'kampf' sondern 'feindschaft' bedeutet." He adds that uno similar phrases are to be found. To this I wish to remark firstly that in fcehde the idea of "hostility" has more or lesss distinctly passed over into that of "hostile deed, or action", "figight", also in 1l. 109, 1380, 1537, 2513, 2618 , etc., secondly that, if this be the case, there seems to be no essential difference, between wiz zefeohtan 1083 and fohde zeslean 459. Neitheer phrase occurs more than once in the poem. In Elfred's nworks we find size zeslean (Bede) synonymous to size zefeohhtan (Cura Past.). There are difficulties enough in Beowulf: without creating fresh ones.

67. Siððan ba fahððe feo pinzode, . sende ic Wylfimzum ofer waeteres hrycz ealde nadmas . 470-472.

sippan zeara iu hrusan heolstre biwrah and ic hean ponan wod winter-cearriz Wanderer 22-24.

Both these passages are considered faulty by many scholars. Trautmann sayys of the former: "Zwischen sidðan und $b a$ ist ein schon ofteer verlangtes ic einzuschieben, das zwar der vers, nicht aberr die grammatik entbehren kann." In the latter, ETTMǘLlezR 1), GRein, RIEGER 1), Wülccker, SweEt, JACOBsen 2) changee heolstre into heolster. I here place the two attacked sentencees together for mutual support. In both, the pronoun is givenn only in connection with the latter of two co-ordinated verbs. . This is a construction of which I can but say that it is in harmony with the peculiar ways of Old English versificatiom, where a pronoun is not unfrequently omitted and where often a fuller expression follows on a less definite one. I therefore consider BosworthToLLER's translation (p. 9£8) correct. An analogous passage is the following:

nymed nyd-badee, næenezum arad

leode Deniza, ac he lust wized 598-599.

1) See WüLCKer.

2) Darstellung der syntaktiischen Erscheinungen im ags. Gedichte vom Wanderer. Rostock 1901. 
68. atwiton weana dal 1150.

of poet him on innan ofer-hyzda dcel weaxed and wridad 1740-41.

$p_{y}$ ic Heoðobeardna hyldo ne telze, dryht-sibbe dael, Denum unfacne 2067-68.

\section{Biowulfe weard \\ dryht-maðma dol deaðe forzolden 2842-43.}

Bosworth-Toller, under dal, do not bestow one word on the peculiar usage of the word exemplified in the above quotations. Under dryht-sib they render 1. $2067 \mathrm{f}$.: "I esteem not part of the Heathobeards' lordly kinship to the Danes guileless." Heyne-socin say: "Oft hebt doel die einem Individuum überhaupt eigene Summe einer Sache oder Eigenschaft hervor", and translates $1.1740 \mathrm{f}$.: "bis ihm im Innern sein Teil des Uebermuts wächst, d. h. was ihm überhaupt an Uebermut eigen ist, sein Uebermut"; likewise l. $2842 \mathrm{f}$.: "Beowulf ward sein Teil der herrlichen Schätze mit dem Tode vergolten, d. h. was ihm an herrlichen Schätzen bestimmt war, was er davon im Drachenkampfe erobern konnte." HaLL renders 1. 1150: "blamed them for their share of woes"; and so forth. This is not satisfactory. Doel, here, does not mean "part", nor yet simply the individual share in a thing or experience, feeling or quality. The share must be a large one. The idea of something considerable, frequent, or numerous, is always prevalent, as in the modern a deal (a good deal, a great deal). Although GRein was partly on the right track, and Cosisn ${ }^{1)}$ (in 1892) briefly stated the true signification, the editions keep on misleading the student. Weana dal $1150=$ "their manifold misfortunes"; ofer-hyzda dcel $1740=$ "a good deal of presumption", "great pride"; dryht-sibbe doel $2068=$ "their great friendship"; dryht-mađma dol $2843=$ "his numerous treasures", "the many costly things"; and so forth. Further examples: Beow. 1752, 2028, 2245, wintra doel, "a good many years" Wanderer 65 ; wundres dacl, "a great wonder" Cynewulf's Riddles $61,10$.

1) p. 33 . 
69.

paer se zoda saet,

Beowulf Jeata be bcem zebrođrum twam 1190-91.

Trautmann says: "Solche verbindungen wie Beowulf Geata (Geata als gen. plur. genommen) sind sonst m. w. nicht nachweisbar, wol aber sprechen solche wie Wulf Wonreding für nom. sing. Geata." Cf. Beowulf Scyldinza 53, Hrepel Jeata 374, Beowulf Jeata 676, Hnof Scyldinza 1069, Hizelac Jeata 1202. The first Scyldinza is "metrisch fehlerhaft und sprachlich auffallend", says Tradtmans. What about the second (1. 1069)? The genitive is certainly proved through the above quotations - as far as the late MS. is concerned. As for the original shape of the poem, in this case and many others, cf. the second footnote on p. 220.

70. nu oper cwom

mihtiz man-scaða, wolde hyre maz wrecan, ze feor hafad fahde zestaled, boes be pincean moz pezne monezum, se be after sinc-zyfan on sefan zreoteb, hreper-bealo hearde 1338-43.

$p_{a}$ ic on morzne zefrazn moz oðerne billes eçum on bonan stalan, par Ongenpeow Eofores niosad 2484-86.

These passages, the only two in Beowulf where the verb (ze)stcelan is employed, have both been misunderstood. I venture to say the same of:

\section{leoht sceal wið pystrum,}

fyrd wid fyrde, feond wid odrum,

lad wið lape ymb land sacan, synne stcelan Gnomic Verses Cott. 51-54,

Feowertiz daza fahde ic wille

on weras stalan Genesis 1351-52,

and (the corrupt):

hu hie him on edwit oft asettad

swarte susl-bonan... staeled

fahðe \& in firne par Je hie drihten

ecne anwaldan oft forzeaton

Chr. \& Sat. 273-276 (639-642), 
so that the lexicographic account of the verb (ze)stolan requires a thorough revision. ( $($ e)stalan hwoet on hwone means "lay something to somebody's charge", hence "call him to account for it", "avenge it on him". In the majority of sentences quoted by Bosworth-ToLLER, the idea of charging, or accusing, or upbraiding, is quite distinct: on me fyrene gestaelan, "impute crime to me"; $\delta y$ lass on me mage leagung beon gestceled, "ne mendacio dignus efficiar"; Jara đinga ठe hine mon on stcelde (accused him of); ðec soð on stceldun, "brought a true charge against thee"; stocldon on me Joct ic ne nyste, "quae ignorabam interrogabant me"; similarly: us synne gestoelan, "accuse us of sin", etc. The object of the active (the subject of the passive) clause is in each case a real or imputed crime or injury (fyrene, synne, etc.). As quite analogous to these sentences I construe the fifth of the opening quotations. It refers to such souls as have been sent to Hell, and there endure the Devil's conversation. The subject of staeled is missing, apparently Satanas or some similar word. Fahde \& in firne contains one word too many. (Confusion and repetition of $\&$ and in I have come across more than once in old MSS.) Thorpe leaves the text unamended. BouterWeK 1), GREIN, WüLCKER, and BosWORTH-Toller read fohde in firne, Dietrich 1), foehde in firnum. Not one has suggested faehde \& firne! And yet this is such a common collocation; cf. foehde and fyrene Beow. 137 and 2480, fahðe and fyrena 879 , fyrene and frehðe 153 . The way in which all those editors and lexicographers have dealt with the passage would to me appear most surprising, did not the misapprehension of stceleð ("Stcelep frehðe, declares enmity", Bosworth-ToLLer) account for the fact. One error has generated another. How many of the learned gentlemen take in firne (in firnum) to mean "in the torment(s) of Hell", I have not tried to ascertain; nor do I know what sense they, from their point of view, can possibly wrest out of the succeeding relative clause. Something seems to be amiss also in that clause, as there is no alliteration in the latter half of the third line; but it need not be anything that influences the meaning. At all events the clause, as it stands, gives, in my way of looking at it, perfect sense;

1) See WüLCKER. 


\section{hu hie him on edwit oft asettad, swarte susl-bonan, [Satanas] staeled, foeh $\delta$ and firne, bar de hie drihten, ecne anwaldan, oft forzeaton,}

"how they, the black tormenting manslayers (i. e. devils) oft reproach them with, and how Satan accuses them of, the enmity and crime in which they so oft forgot the Lord, the eternal Monarch."

The same enmity against God which is the object of stoeled in the passage now discussed, is the object of stoelan in the quotation out of Genesis. Thus foehðe 1351 is not used "of the threatened deluge" (Bosworth-Toller p. $908 \mathrm{a}$ ); it does not mean "vengeance" (p. 264 b); it does not denote God's "vijandschap" against mankind (CosIsN p. 23); but it expresses the relation of the sons of Seth to God after their taking wives out of Cain's cursed race (Gen. 1248-52, 1257-59). Those who had before been on friðe (1262) with their Creator, became war-lozan (1266) through their association with God's feonda race (1259); so that the expression foehde is in perfect keeping with the whole way of putting matters. Hence the correct translation of the lines is this: "During forty days I will avenge on men their hostility."

Just as here the idea of accusing or upbraiding has developped into that of avenging, so also in the quotations from the Gnomic Verses and Beowulf. SweEt renders synne staclan by "institute injury, or hostility", Cosisn by "veete, vijandschap bedrijven". Synne, however, means an infringement of divine or human law, wrongdoing; it is not used of hostility in general, or looked on as lawful; it is used of wrongful hostility or invasion, injury. The clause means: "call to account for injury", "avenge [wrongful] hostility".

Grendel's mother had her injury to avenge - the killing of her son, spoken of before as $p a$ fohde pe pu zystran niht Jrendel cwealdest (1333-34). She wolde hyre ma'z wrecan (1339) and - far has she avenged (far has she gone in her revenge of) the hostile deed. (I see no reason for explaining feor as a comparative.)

The sentence not yet discussed here has been more grievously misunderstood than the others. HEYNE gives, without 
reserve, an explanation which is next to unparalleled for farfetchedness, and helplessly clashes with the statements of the poem itself. HoLder is likewise in the dark. BosworthToLLER's translation (p. 908 a) is essentially right; only the comment on it added within brackets, and wisely marked with a note of interrogation, is wrong. What Cosiss says of the passage is, in my opinion, as correct as his acceptation of the other instances is erroneous (he does not mention Gen. 135152). There would be no occasion, then, to dwell on this any further, did not Herne-Socin and Holder, in the latest editions $(1898,1899)$, still adhere to the old explanation. (Wyatt and Hall follow Cosisn.) Before I saw Cosisn's Aanteekeningen, I had arrived at exactly the same conclusions. I will give my remarks below, within brackets, in their original shape. Although they say essentially the same as Cosisn's paragraph, I may, perchance, be more fortunate in persuading Mr. Socin and Mr. HoLDER, and thus reach the numerous students who benefit from their editions.

[When Hæðcyn had fallen in the battle against the Swedish king Ongenpeow, his men fled into a forest. There they would have been annihilated next morning, had not Hæðcyn's younger brother Hyzelac, come to the rescue. Then the Swedes in their turn had to retire, and the two invading divisions joined in pursuit of them. In the ensuing battle two brothers in Hyzelac's force, Wulf and Eofor, distinguished themselves: the former wounded king Ongenpeow, but received a smart blow in return; the latter managed to kill the king, and divested him of his armour. Heyse says: "da erfuhr ich, dasz am Morgen ein Bruder den andern mit Schwertes Schneide zu dem Mörder hinzog, d. h. der Schwertstreich, mit dem Ongenpeow Wulf niederschlug, trieb dessen Bruder Eofor zur Blutrache". A murdered brother drawing with the edge of the murderer's sword the other brother to that murderer is, indeed, a wonderful performance. And Wulf did not die! He recovered (hyne zewyrpte 2976), returned safely to his land, and received there from the king hund pusenda landes and locenra beaza! Ongenpeow was in reference to him no murderer. It was Hæðcyn that the Swedish king had slain in the battle; his bona he was. And the one who wanted to take "Blutrache" was, of course, king Hyzelac. So he did, too, in the 
battle where his man Wulf wounded the Swedish king and Eofor administered the fatal blow. Accordingly, in 1. 1968, Hyzelac is called bona Onzenpeoes. Besides, him and he in 1. 2490 cannot refer to Eofor! Thus, by taking matters as they are, and allotting to stcolan the same signification as in the preceding instances, we clear all difficulties at once: "I have heard that then in the morning one brother avenged the other on the murderer with the edges of swords."

It is almost superfluous to add that also the above-mentioned hyne zewyrpte, which, as is well known, means "recovered", is falsely rendered in Herne's Glossary. Wulf, when wounded, did not immediately "aufspringen" or "sich erheben". He remained lying on the battle-field till his country-men were masters of it. Then only did they bind him up and arcerdon him! - Cf. Postscript.]

71. Oft seldan hwor after leod-hryre lytle hwile bon-zar buzed, peah seo bryd duze! 2029-31. Wundur hwar ponne eorl ellen-rof ende zefere lif-zesceafta, ponne lenz ne maz mon mid his [ma]zum medu-seld buan 3062-65.

Sievers ${ }^{1)}$ gives the right explanation of the latter passage. Wundur means "a wonder", hence "something causing wonder or uncertainty", "something uncertain", just as the modern $I$ wonder (if) is expressive of doubt. This wundur, placed before the interrogative hwar, is in itself as good as a whole clause: "uncertain it is, where". Such a construction is not due to an accidental omission; it is not a piece of poetical license; it is not harsh, nor awkward. It is an easy and natural brachylogy used in prose as well as in poetry. Cosisn adduces: Uncuð hu lonze (uncertain it is how long) par swa zelcerede biscopas sien Cura Past. p. 8, 1. 3 (E.E. T. S. 45); uncuð peah pe he sloepe Elfric's Homilies (III) p. 390, 1.119 (E. E. T.S. 82). The first ponne is an adverb ${ }^{2}$ ), not a conjunction, as Heyne-Socis put it. - Thus prepared, we will pass over to $1.2029 \mathrm{ff}$., a period which has puzzled so many brains
1) Beitr. 9, 143.
2) Thus: Wúndur, hwar pónne. 
and set so many pens a-going, yet without having hitherto received a satisfactory explanation. GRUNDTVIG suggests a violent alteration. So does RIEGER. 1) KLUGE says first 2): "mit oft seldan hwar weiss ich ebensowenig etwas anzufangen als die bisherigen erklärer"; then, in HoLdER's edition, he introduces: seldan ware (they made a treaty). BugGe ${ }^{3}$ ) commends this, but wants to strike out oft. CosisN, in his Aanteekeningen, gives up an earlier explanation, "zelden pleegt ergens", and thinks that "wat te emendeeren is, is juist seldan hwar", for "gewoonlijk en zelden sluiten elkander uit". HeYne-Socin, WüLCKer, and Wyatt insert no, in analogy with oft nalles ane 3019 , oft naloes seldan Ps. 74, 4 . They believe, like KöLbing ${ }^{4}$ ), that no may even have stood once at the beginning of the line now defective. Zupirza thinks there was no room for it. Such prosodists as frown even at oft, will do so still more at oft no. I explain the unaltered text in the following manner. Oft only marks the general applicableness of the sentence, which is a gnomic one: "as a rule", "always". It is no more irreconcilable with the following seldan than always is with seldom in the modern: He has always called very seldom, which of course means: "he has always been in the habit of calling seldom", "he has always been a rare guest". Hwar does not mean "anywhere" ("irgendwo", Heyne-Socis), nor yet is it an interrogative adverb; it is a general relative adverb, and is, just as in the three oldest instances quoted in $\S 175$ of my essay on the relatives), preceded by a negative (no seldan would make an affirmative expression!). Seldan hwoer is the same brachylogy as the one already discussed: "there is seldom a place where", "it rarely happens that". Lytle hwile is not expressive of duration (as it might very well have been), but of a point of time; it does not mean "for (or during) a short time", but "when some time has elapsed". Seo bryd does not directly refer to Freawaru, king Hroðgar's daughter, as KLUGE ${ }^{6)}$ thinks, and as BARNouw, the latest to my knowledge to discuss this passage, energetically maintains. "Mit seo bryd", he says "),
1) ZfdPh. 3, 404.
8) Beitr. 9, 190.
8) Beitr. 12, 368.
๑) Archiv 56, 107.
в) Beitr. 9, 190.
s) The English Relative Pronouns, Lund 1897.
') p. 26. 
"ist entschieden Freawaru gemeint; denn wer die verse als eine äusserung allgemeiner lebensweisheit auffasst 1), misst dem artikel eine function bei, die für den Beowulf viel zu modern ist." Baknouw himself allows ${ }^{2}$ ) that where a wellknown custom is concerned, an idea not yet expressly mentioned in the same context, but necessarily connected with that custom, may be introduced, even in Beowulf, by a noun preceded by the definite article. And it not only was a custom to give young princesses in marriage to secure peace between contesting nations, but the poet felt it as such, too, for he uses the characteristic expressions friðu-sibb folca and freodu-webbe, in the same section and in the preceding one (1l. 2017, 1942), about two other royal ladies, Freawaru's mother and Prydo. It is quite a different thing that the poet - of course - had Freawaru in his mind, when he framed the general rule.

My translation, therefore, is this: "As a rule (on the whole), there is seldom a place where (there is seldom a case in which, it seldom happens that) the spear rests (is still resting) a little time (when some time has elapsed) after the fall of the prince, even though the bride may be a good one." In German: "Es ist immer ein seltenes Ereignis, dass", etc.

72. he me [madma]s zeaf, sunu Healfdenes, on [min]ne sylfes dom 2146-47. pat se peod-cyning atafian sceolde Eafores anne dom 2963-64.

Heyne-Socin render the spaced words by "zu meiner eigenen Verfügung" and "Eofors Macht allein". BoswortнToLLER (p. 207 b) render similar expressions by "in your own will", "of his own free will". These translations are more or less unsatisfactory. Thorpe, Sweer, and Wya'T"r use the word "choice", which is much better. What the 0 . E. sylfes dom (azen dom) and an dom really mean, appears from a comparison with the 0 . Icel. sjalfdcemi and eindomi: the right or power for one of litigant or fighting parties to decide for himself, or alone, what satisfaction is to be given by the other;

1) So do e. g. Lichtenheld in ZfdA. 16, 343, Cosijn, and Author.

2) p. 22 . 
hence, in general, how much one is to have or take from the other. Thus in 1. 2147: "as many as I myself decided", "as many as I wished to have"; in 1.2964: "what Eofor as sole judge decided", "Eofor's absolute judgment". Similarly: sylfes dome (as many as he pleased) Beow. 2776; pa gebead he him hiera agenne dom (to decide for themselves how much they would have; as much as they wanted; their own choice) feos $\&$ londes Chronicle, ed. Thorpe, p. 84; syllan sa-mannum on hyra sylfra dom feoh wið freode Battle of Maldon (Byrhtnoð) 1. $38-39$.

73. eorl Onzenpio ufor oncirde 2951.

Hexne-Socin and Holder translate ufor by "höher", Wrater by "higher, upwards, on to higher ground". This may be right. However, we know nothing of the relative position of Ravenswood and king Ongenpeows stronghold. Probably BosworTH-TOLLER are right in their observation that "distance rather than height is marked". Very distinct is a passage in Alfric's Homilies, where the heathen standing outside the temple were asked by St. John poet hi ufor eodon fram bam deofles temple (SweEr's Reader p. 69, 1. 244). The temple was built rather on a hill than in a hollow; but the people were to go further away (draw back, withdraw, retire), so as not to be crushed by the toppling walls, when God made the temple fall. I will also mention the M. H. German hoher, uf hoher. Hagen and Volker, for instance, wolden niht hoher stan (stand back, step out of the way), when Attila and his Queen came out of Church. The master of the hunt, when Tristan objected to the Cornish way of cutting the venison, asked him to show his own method, and stuont uf hoher do.

\section{List of passages discussed.}

I include some lines out of Beowulf mentioned in my essay on The English Relative Pronouns (ERP), Lund 1897.

Line 6. No. 60 .

Beowulf.

15. ERP p. 21 (TrautmanN has afterwards taken the same view).

$n$ 22-24. No. 61.
Line 31. No. 62 .

$\eta$ 128. No. 63 .

" 158. Nr. 64 .

n 168-169. No. 65

459. No. 66.

470. No. 67. 
INTERPRET. AND EMEND. OF EARंLY ENGLISH TEXTS.

Line 488. ERP p. 57 (or: "through death taking those away").

525. No. 64 .

n 647. No. 64 (second footnote).

711. No. 65, end.

765-766. ERP p. 32.

1048. ERP p. 51.

1141. ERP p. 35.

1150. No. 68.

1191. No. 69.

1244. No. 60.

1272. No. 64.

1291. ERP p. 78.

1340. No. 70 .

1396. No. 64 .

1436. ERP p. 57 (cf. 1. 488).

1654. ERP p. 45.

1740 (1752, 2028). No. 68.

2029-31. No. 71 .

2068. No. 68.
Line 2147. No. 72.

$\eta 2245$. No. 68 .

,$\quad 2448-49$. No. 61.

" 2484-85. No. 70.

2540. ERP p. 24.

2733-35. ERP p. 22.

2776. No. 72.

2843. No. 68.

295̄1. No. 73.

2964. No. 72.

3062-65. No. 71 .

" 3165. ERP p. 49.

Chr. \& Sat. 274-275 (640-641).

No. 70.

Cynew. Ridd. 61: 10. No. 68.

Genesis 1351-52. No. 70.

Gnomic Verses Cott. 54. No. 70.

Wanderer 22-23. No. 67.

65. No. 68.

Corrigenda to Anglia N. F. XIV.

P. 364, 1. 3, and p. 376, middle. Read: Anglia N. F. XIII.

P. 373, 1. 6. Read: the end of no. 50 .

Lund in May 1903.

ERNST A. Kock.

Postscript (October 1903).

While reading the advance-sheets, I receive HEYNE-Socis's 7th edition. It has adopted the right translation of hyne zewyrpte, 1. 2976. Other things discussed here are unaltered. - Cf. my review, which will appear in the 20th vol. of Arkiv för nordisk filologi.

E. A. K. 